\title{
CUARZO AURA. \\ DESDE QUE EL ARTE ES ARTE. DESDE QUE EL MUNDO ES MUNDO
}

\author{
CUARZO AURA. \\ SINCE ART IS ART. SINCE THE WORLD IS WORLD \\ Estudio Almaro. Diciembre 2019
}

\author{
Irene Estrella León \\ (Universidad de Málaga, España) \\ ylees2390@gmail.com
}

Recibido: 01 de septiembre 2020 / Aceptado: 07 de septiembre 2020

\begin{abstract}
Todo comienza con una sencilla premisa. Por muchos conceptos, ideas, productos o artilugios que intervengan en algo, siempre terminamos viendo la cara pública, la finalizada, la sencilla. Donde ya ha pasado todo. Un parto es una nueva vida tras la que hay meses de gestación, de incertidumbre, de músculos trabajando de una nueva manera, de órganos creciendo, ensanchando, aumentando para terminar con un alumbramiento repleto de ilusiones, nervios y dudas, las cuales se disipan al concluir ese nacimiento, donde, si todo ha salido bien, te invade la satisfacción y la plenitud. Lo mismo ocurre con el emprendimiento artístico y cultural.
\end{abstract}

Si bien el arte no es más que el reflejo de la sociedad del momento y, los artistas, los narradores que nos convierten en participes de su propia visión, enseñándonos un nuevo prisma bajo el que comprender los hechos, ¿cómo no apoyar aquellos proyectos que no forman parte de lo meramente institucional? Desde que el Salón de los Rechazados sirviera como circuito artístico paralelo en la segunda mitad del siglo XIX, acogiendo las piezas que no encajaban en la estética del momento, los artistas adquirieron una mayor voz, reivindicando su trabajo y apostando en lo que ellos firmemente creían. A partir de este hecho histórico, el mundo cultural se tornó más abierto, independiente y poliédrico, abriendo camino a unas futuras generaciones que aún hoy siguen esa estela. 


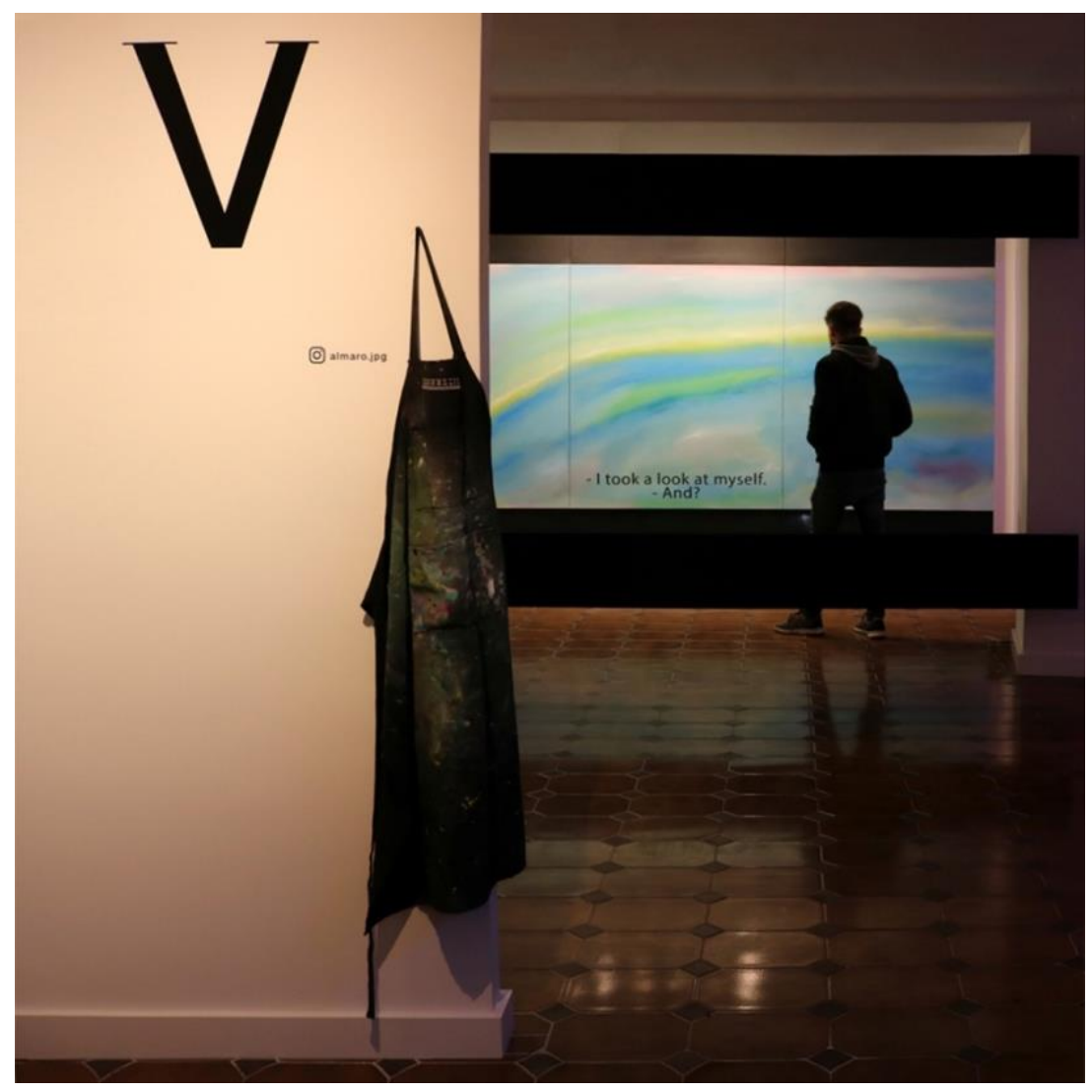

Resulta imposible que las instituciones puedan abarcar toda la cultura existente, pues, ya sea por falta de recursos, de tiempo u otros factores, como con qué se identifica cada organización para seguir siempre un mismo discurso expositivo, limitando y seccionando el sector. Como si de un embudo se tratase, se filtran ciertos proyectos mientras que los demás quedan en la parte ancha del mismo, esperando a ser contemplados.

Por suerte, en la actualidad el arte está más emulsionado con la vida cotidiana que en el pasado y dichos circuitos nos envuelven en muchas ocasiones sin que nos percatemos de ello, provocando que la cultura sea más participativa con el público. A diferencia del pasado, donde las visiones artísticas se podían tratar de una forma más individualista, a día de hoy tanto los artistas como cada pieza del engranaje de la gestión cultural apuestan por un diálogo más cercano con los espectadores, globalizando así el pensamiento colectivo de una sociedad, haciendo el arte más colaborativo y participativo: bares o restaurantes colaboran con artistas locales, espacios a pie de calle afloran como pequeñas galerías independientes, redes sociales en las que se crean galerías virtuales para dar una mayor visibilidad, o nuevos estudios de artistas, como es el caso de Estudio 
Almaro donde confluyen arte, color, energía y música, además de colaboraciones con otros artistas emergentes de diversas corrientes.

Tras meses trabajando por circuitos de arte alternativos con diferentes proyectos en los que la idea de luz iba transmutando paulatinamente en colores y energía, se gestaba de manera paralela el deseo de tener un lugar propio, diferente, con un sello de identidad firmemente marcado. Un espacio que supusiera un punto de inflexión en el itinerario cultural malagueño con la aspiración de convertirse en una referencia para una nueva manera de entender el arte contemporáneo en la ciudad, acogiendo en sus entrañas diseños expositivos realmente asombrosos como fue el caso de Cuarzo Aura; una muestra que tuvo lugar en Diciembre de 2019 donde, el artífice de todo esto, Alejandro Martín -Almaro- (pues es el dueño del lugar y el artista plástico que diseñó la exposición) creó su V capítulo mineral.

Almaro toma los minerales como ejemplo de un elemento tangible a través del cual aunar el plano energético y el terrenal, extrapolando sus características y atributos para crear un antecedente, engendrando de esa premisa el discurso expositivo. Sus obras concentran así el simbolismo mineral llevado a los lienzos, donde los colores invaden el plano metafísico, transformando lo tangible en intangible.

En Cuarzo Aura, el epicentro creativo crece en torno a lo caprichoso de las luces iridiscentes y su relación con la frecuencia de color que tenemos en cada momento de nuestra vida. Entre otras finalidades, el arte busca remover algo en el público, crearle sentimientos y emociones, lo que convierte a las piezas que conformaron dicha muestra en atemporales, pues cada vez que las contemplas puedes sentir algo distinto u opuesto en función al estado emocional en el que nos hallemos. Desde el plano energético, hay colores que nos complementan en un momento concreto, teniendo relación con algo que nos está ocurriendo. Sin embargo, con el tiempo, podemos llegar a desecharlo, pues ese transmuta en eterno. Lo que nos lleva a ver dicha frecuencia cromática con nuevas percepciones.

No existe una imagen reconocible en estos lienzos, pues su finalidad no es otra que la evocación de los sentidos y ver qué crea en cada uno de nosotros, encendiendo los tonos y colores hasta ajustarlos a una gama cromática concreta en cada una de las 22 piezas que construyen la exposición. 


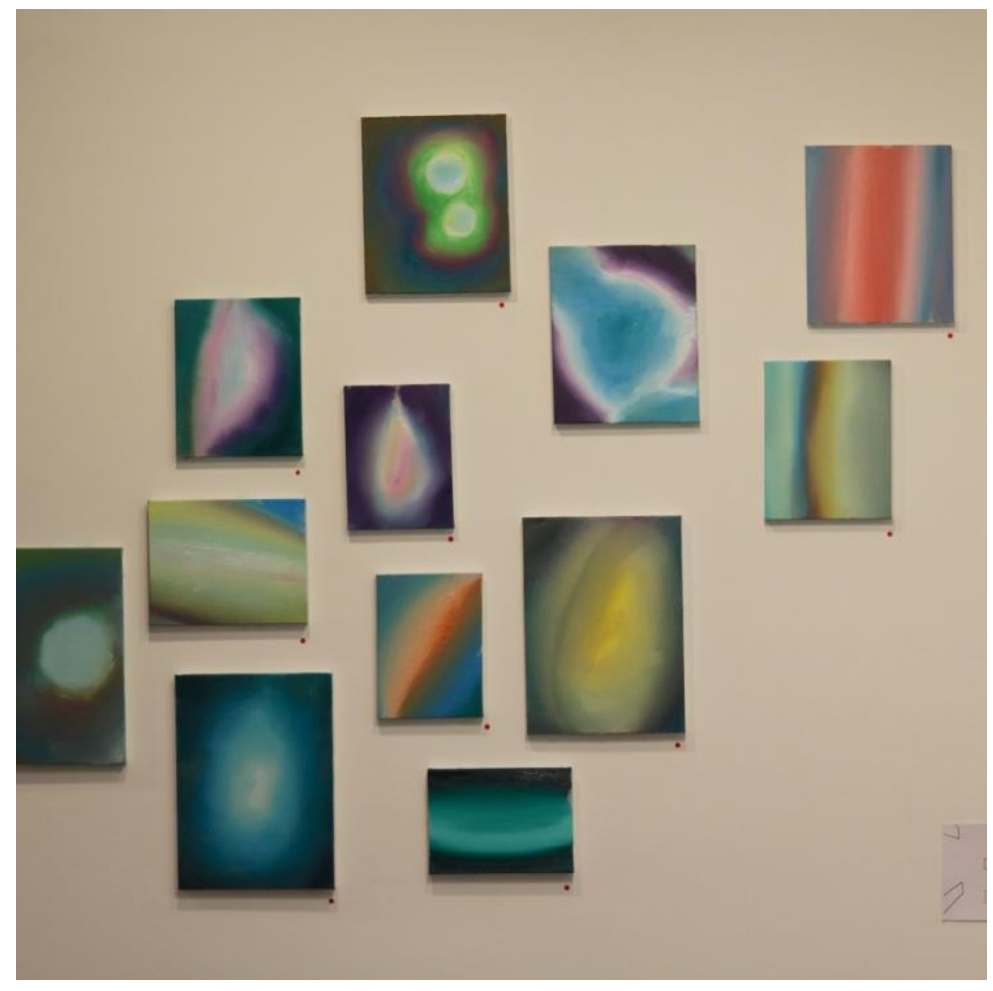

La creación culmen es una obra de gran formato construida en dos partes para conseguir experimentar lo que el autor nos quiere transmitir: dos franjas negras, como si de un recorte cinematográfico se tratase, nos atrapa entre ellas y un lienzo repleto de luminosidad que reza una frase que nos invita a la reflexión: me he mirado de frente, iy bien? Con ello Almaro nos transporta a formar parte de su obra, haciéndonos dudar si formamos parte de esta o no, aunando el plano físico y el emocional con el secuencial audiovisual, creando la ilusión de poder integrarte con los colores.

La exposición acaba con la frase cada color se expande como una flor que se abre, apareciendo también al final de la hoja de sala -un video repleto de imágenes llenas de luz, florecimientos y un alumbramiento-. Un tono reflexivo que acompaña a todo el conjunto aludiendo a momentos cotidianos, como los nacimientos, donde pasamos de un lugar oscuro a otro donde los colores invaden cada sentido e instante de nuestra vida cotidiana, insuflando de nuevos matices nuestra realidad tangente.

Como resultado de toda esta experiencia expositiva y si no hubiera sido por los circuitos de arte alternativos que afloran en Málaga, posiblemente Cuarzo Aura no hubiera existido. Es importante por ello apostar y apoyar a los nuevos lugares que poco a poco van surgiendo en pro de la cultura local, visitándolos, formando parte de sus proyectos e involucrándonos con ellos porque, igual, no todos creamos arte, pero el arte 
sí forma parte de todos: es nuestro legado, nuestra identidad como sociedad, nuestro día a día.

Porque el mundo y el arte (ya sea o no emergente y en cualquiera de sus vertientes) están tan estrechamente unidos como si fueran las dos caras de una misma moneda: el arte no sobrevive sin el mundo y el mundo no sobrevive sin el arte. Ambos se necesitan, teniendo una relación que se retroalimenta desde que el arte es arte y desde que el mundo es mundo. 